from under gypsy moth bands at Wallingford by Mr. Caffrey and his assistants; this idea might be employed very successfully as a means of collecting tree-infesting insects.

Oberea oculata Linn. This is a European species collected at New Haven, July 9, by Mr. Walden; one specimen being taken near the Experiment Station. It is recorded as living in willow.

Pytho niger Kirby and planus Oliv. Windsor, January 2, 1907. Taken from eells under bark of dearl and dying white pine-A. F. Hawes.

Rhipiphorus limbatus Fabr. and flaripennis Lec. Common in flowers near the Station.

Tricrania sanguinipennis Say. Lyme, April 3, on plowed ground in which a species of bee had made numerous burrows.

Homorus undulatus Uhler. New Haven. Common Disfigures the leaves of lily-of-the-valley on the Station grounds. (See Fifth Rept. State Ent. Conn., p. 259, Plate VI.)

Otiorhynchus sulcatus Fabr. and O.ovatus Linn. Very conmon in Connecticut, and occur in numbers at arc lights

Barypithes pellucidalis Boh. New Haven, May. Common at are lights.

Stephanocleonus plumbeus Lec. Prospect, August 15-W. E. Britton. New Haven, May 23, July 13-B. H. Walden. Unusual in this section.

Phytonomus meles Fabr. This imported species discovered by Dr. E. G. 'Titus is very common in the vicinity of New Haven. During May, I found that it greatly outnumbered $P$. punctatus Fabr. and nigrirostris Fabr. Taken also in Meriden, May 29, by W. E. Britton.

\title{
Notes on a Sarcophagid Found in a Turtle.
}

From rather a large number of native turtles collected in the vicinity of New Haven, Conn., for dissecting purposes at the Sheffield Scientific School of Yale University, one was found to be infested in the axilla with maggots of a Sarcophagid.

The maggots, although nearly full grown, were only noticeable after close observation as they were well concealed within a blackened, elevated, horny funnel about $1 \mathrm{~cm}$. in diameter and nearly $1 \mathrm{~cm}$. in depth. The extreme edge of the funnel was composed of 
the scales of the turtle standing nearly perpendicular to the surface of the body, gradually becoming thicker with the integument as it continued inward. On removing a portion of the blackened material within the funnel, six large maggots were disclosed, apparently feeding on the fresh adipose tissue. The turtle was killed and this infested portion with the maggots was removed and placed in a glass tumbler partly filled with earth and covered with cheese cloth. This was on April 26, and they pupated on the following day, having left the mass of tissne and crawled into the earth. The adult flies began to emerge on May 22 and continued until May 24, when the total number was complete. These, as well as the puparia were determined definitely as Sarcophagids, but owing to the somewhat chaotic conditions of this family the identity of the species was uncertain. The surroundings being unfavorable for keeping them alive, they all died by May 28 and the writer was unable to try with them any reproduction experiments on caterpillars.

\section{T. L. Patterson.}

[Mr. Patterson has asked me to add a short note regarding similar recorded cases of turtles inf st d ly S.rcophagid larve. Apparently the first ref-rence to such larve, definitely shown to belong to a speies of this family was made in 1890 by Wheeler (a supposed Bot-fly Parasite of the Iox-turtle. Psrche, Vol. 5, p. 403). He succeeded in rearing adults of a Surcophaga from larvæ found in a pocket beneath the skin upon the neck of a turtle which had been taken near Windsor, Connecticut. Wheeler refers to a previous account by Packard (American Naturalist, Vol. 16, p. 5.88, 1882) of similar larva from the ncek of the same species of turtle collected at Middleboro, Massachusetts. As no adults were reared, Packard supposed the larve to be those of some species of bot-fly. More recently, Mr. H. G. Barber has described at a meeting of the New York Entomological Society, a turtle similarly parasitized.]

Editor.

\section{ERRATA.}

The following corrections and additions should be made to the article by C. s. Ludlow on “The Philippine Mosquitoes," published in the last number of Psyche:

Page 125, under Anophelinæ, add to the list, Myzomyia ludlouri Theob.

Page 126, second column, line 39, for ludlowii, read ludlowi.

Page 127, first column, line 1, for aureosqumatus, read aureosquamatus.

Page 127, second column, remove Hodgesia Theobald, nircocaputis sp. nov., and place under Urotaeniinæ. This genus does not belong to the Harpagomyinæ, and its appearance is an oversight, due to the original arrangement. 

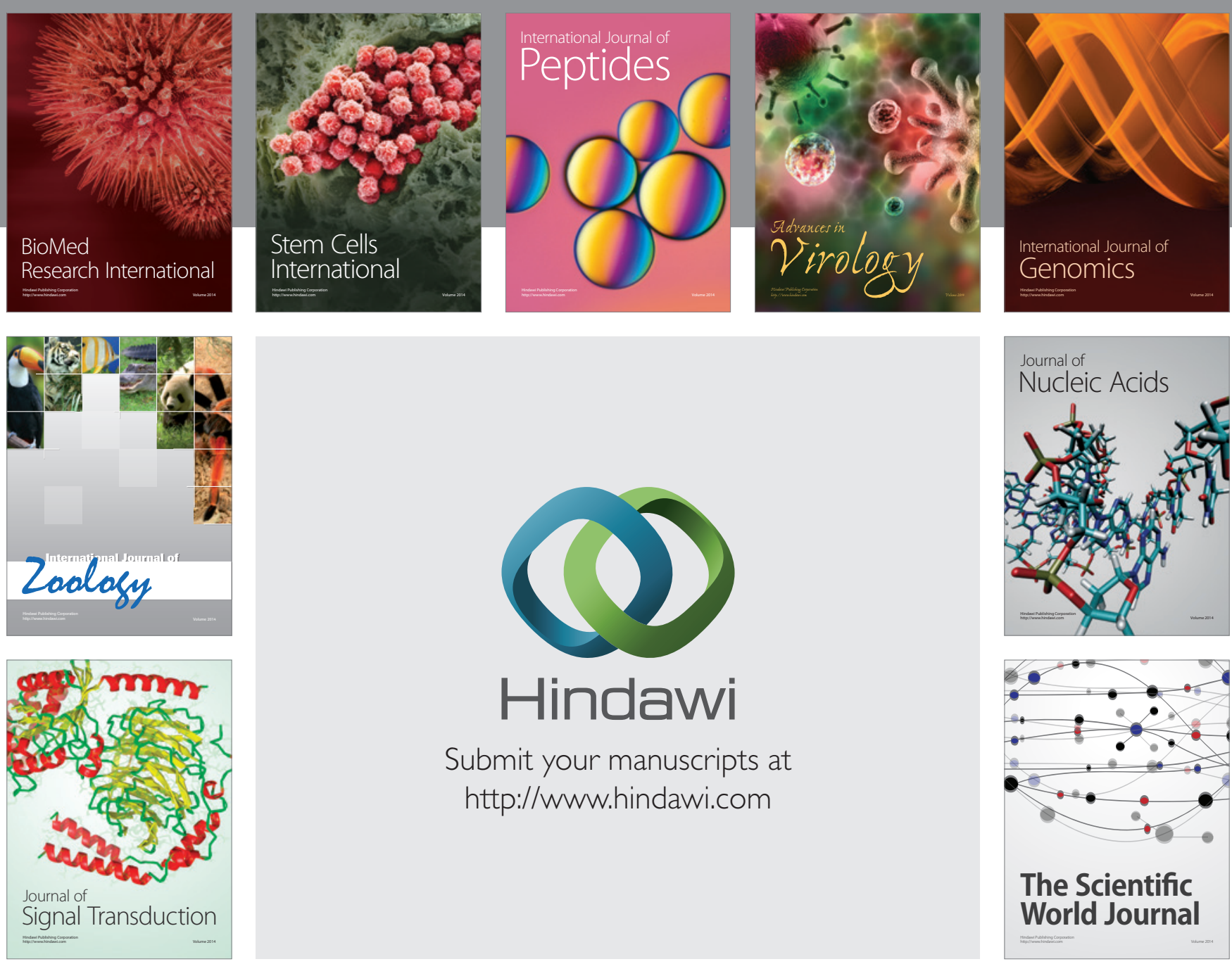

Submit your manuscripts at

http://www.hindawi.com
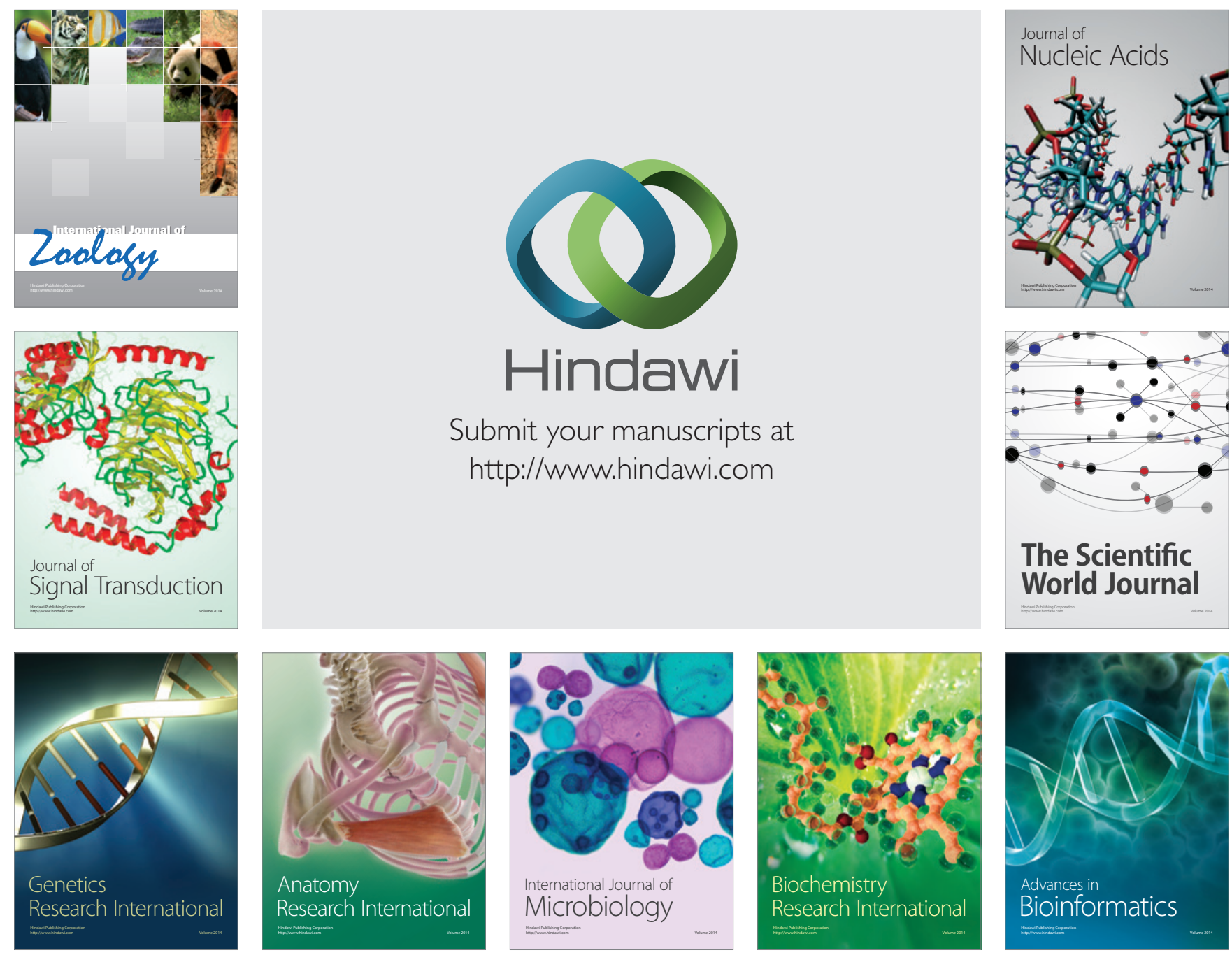

The Scientific World Journal
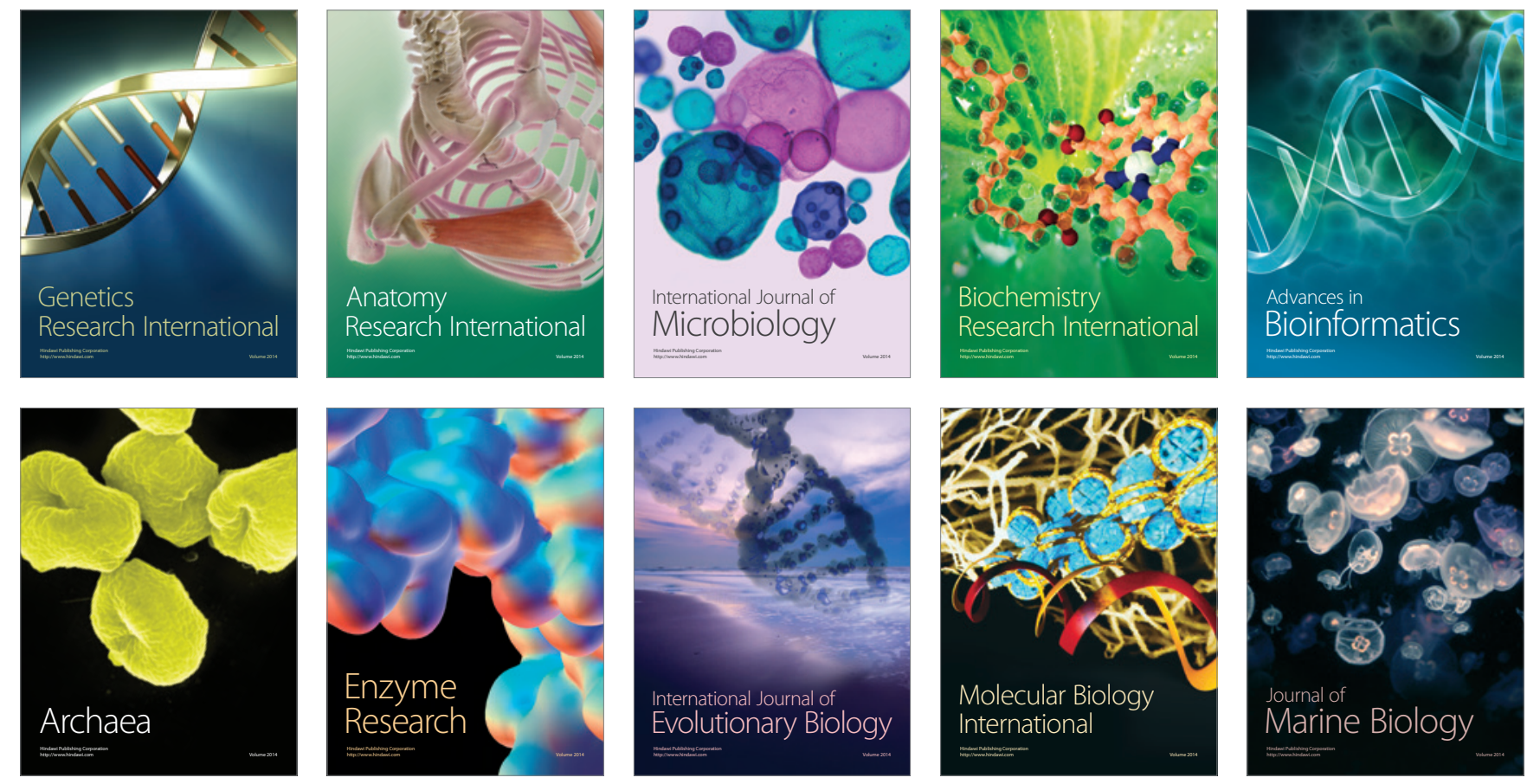